\title{
Ribonucleotide Reductase Subunit Gene
}

National Cancer Institute

\section{Source}

National Cancer Institute. Ribonucleotide Reductase Subunit Gene. NCI Thesaurus. Code C20847.

Ribonucleotide Reductase Subunit Genes (RRM1 and RRM2) encode the M1 Chain and M2 Chain subunits of Ribonucleoside-Diphosphate Reductase, a heterodimeric cytoplasmic enzyme essential in dividing cells that reduces ribonucleotides to deoxyribonucleotide precursors for DNA synthesis in S phase. Enzyme activity closely correlates with the cellular rate of growth and appears to vary with the cell cycle. A substrate site and catalytic site regulate enzyme activity. Allosteric control by deoxynucleoside triphosphates and by ATP bound to M1 prevents DNA replication and cell proliferation. An M1 catalytic site only forms in the presence of M2. M2 synthesis is cell-cycle dependent. p53 regulates ribonucleotide reductase by interaction with p53R2 as well as the $\mathrm{M} 2$ subunit. $(\mathrm{NCl})$ 